Review

\title{
Assessing Nitric Oxide (NO) in Higher Plants: An Outline
}

\author{
Francisco J. Corpas * (iD and José M. Palma \\ Group of Antioxidants, Free Radicals and Nitric Oxide in Biotechnology, Food and Agriculture, Department of \\ Biochemistry, Cell and Molecular Biology of Plants, Estación Experimental del Zaidín, CSIC, C/Profesor \\ Albareda 1, E-18008 Granada, Spain; josemanuel.palma@eez.csic.es \\ * Correspondence: javier.corpas@eez.csic.es; Tel.: +34-958181600
}

Received: 12 April 2018; Accepted: 3 May 2018; Published: 4 May 2018

\begin{abstract}
Nitric oxide (NO) is a free radical and a component of the N-cycle. Nevertheless, NO is likewise endogenously produced inside plant cells where it participates in a myriad of physiological functions, as well as in the mechanism of response against abiotic and biotic stresses. At biochemical level, NO has a family of derived molecules designated as reactive nitrogen species (RNS) which finally can interact with different bio-macromolecules including proteins, lipids, and nucleic acids affecting their functions. The present review has the goal to provide a comprehensive and quick overview of the relevance of $\mathrm{NO}$ in higher plants, especially for those researchers who are not familiar in this research area in higher plants.
\end{abstract}

Keywords: nitric oxide; nitration; S-nitrosation; reactive nitrogen species

\section{A Short Historical Perspective about NO}

The molecule nitric oxide (NO), formally nitric monoxide, has been well known for a long time to be part of the nitrogen cycle. However, during the last 30 years this molecule has become in the center of many physiological and pathological processes in animal and plant organisms. This is because NO has pleiotropic functions at different levels (biochemical, cellular, tissue, and organ) either under physiological and adverse environmental conditions. For many years, the attention on NO was only focused in its contribution to atmospheric pollution since along with nitrogen dioxide $\left(\mathrm{NO}_{2}\right)$ they constitute the group of nitrogen oxides (NOx) which affects the air quality and plant growth [1,2]. However, two scientific reports published in 1987 by two independent groups demonstrated that NO, previously designated as endothelium-derived relaxing factor (EDRF), was involved in the regulation of vasodilation of the blood vessels [3,4]. Then, it was shown that this molecule was generated in mammalian cells from the amino acid L-arginine by a family of enzymes designated as nitric oxide synthases (NOSs) [5]. Later, it was revealed that NO is also involved in both nervous and immune systems in animal organisms. As a historical curiosity, it could be mentioned that in 1960 Fewson and Nicholas published the first report where it was revealed that microorganisms and higher plants could use NO as an intermediate in nitrogen metabolism [6]. Then, in 1979, Keppler (1979) reported that plants treated with different herbicides can generate NO [7]. However during the 1990s, NO research was extended to plant cells, this molecule being involved in a wide spectrum of functions during plant growth and development, as well as in the mechanism of interaction with beneficial microorganisms, defenses against pathogens, and adverse environmental stresses [8-11]. The main goal of this work is to provide a brief overview of the relevance of $\mathrm{NO}$ and derived molecules designated as reactive nitrogen species (RNS) in higher plants. 


\section{Nitric Oxide Biochemistry. How NO Affects Plant Protein Function?}

The function of NO is mainly due to its derived molecules designated as reactive nitrogen species (RNS), which finally interact with different macromolecules affecting their functionalities. Among the most studied RNS, peroxynitrite $\left(\mathrm{ONOO}^{-}\right)$, which results from the reaction of $\mathrm{NO}$ with superoxide radicals $\left(\mathrm{O}_{2}{ }^{\bullet-}\right)$, and $S$-nitrosothiols (SNOs), produced by the reaction of NO with thiol groups. With respect to the latter group, can be mentioned, and it is particularly worth highlighting the interaction of $\mathrm{NO}$ with the tripeptide glutathione (GSH) leading to the formation of $S$-nitrosoglutathione (GSNO) within cells [12]. Moreover, there is increased information about how NO can modulate gene expression [13-16], as well as new related molecules, like nitro-fatty acids $\left(\mathrm{NO}_{2}-\mathrm{FA}\right)$, which have signaling properties [17]. The majority of the research reports on plants have been basically focused on how NO regulates protein functions. Thus far, there are three main processes which have been described to affect protein function: nitration, $S$-nitrosation, and interaction with protein metal centers (metal nitrosylation).

\subsection{Nitration (P-Tyr-NO $\left.\mathrm{N}_{2}\right)$}

Nitration is a reaction which allows adding a nitro group $\left(-\mathrm{NO}_{2}\right)$ into a chemical compound, including proteins, fatty acids, or nucleic acid. In the case of proteins, the most studied modification involves nitro-tyrosine, although there are other amino acids susceptible to be nitrated, including tryptophan, cysteine, and methionine $[18,19]$. Accordingly, this nitro group can cause a gain of function, loss of function, or no effect in the targeted protein, the most usual one being the loss of function. The number of identified nitrated proteins in higher plants and how this modification affects its function has increased [18,20-24]. Thus far, most of the identified proteins in plants that undergo this post-translational modification, usually mediated by peroxynitrite, have been found to provoke a loss of function. Good examples of this issue are some antioxidant enzymes, such as catalase or some components of the ascorbate-glutathione cycle, like ascorbate peroxidase (APX) and monodehydroascorbate reductase (MDAR). However, there are other cases where nitration has no effect, such as has been reported for glutathione reductase $[25,26]$.

\subsection{S-nitrosation (P-SNO)}

$S$-nitrosation, also called $S$-nitrosylation, consists of the covalent attachment of an NO group to the thiol (-SH) side chain of a cysteine (Cys). This post-translational modification (PTM) is recognized as one of the most relevant mechanisms for NO signaling and, consequently, it allows transducing changes in cellular NO to exert its effects. In fact, protein S-nitrosation (SNO-protein), as well as glutathione $S$-nitrosation, giving rise to $S$-nitrosoglutathione (GSNO), should be considered as NO reservoirs [27].

In plants, the number of identified proteins susceptible to undergo this NO-mediated modification under physiological and stress conditions, as well as how this NO-PTM could affect the function of the target proteins, is continually increasing [28-35]. Taking into consideration that this process is reversible, $S$-nitrosation should be assessed as a relevant mechanism of NO signal transduction in the cells.

\subsection{Metal Nitrosylation}

This reaction implies the interaction between NO and transition metals present in target metalloproteins, rendering the formation of metal-nitrosyl complexes. Thus far, in plants, there is insufficient data and the available information comes from haemoproteins identified in animal cells, such as guanylate cyclase and cytochrome c oxidase [36,37]. In this context, the case of non-symbiotic haemoglobins should be mentioned, which are induced under stress, especially in root growth under hypoxic conditions, thus, nitrosylhaemoglobins increase when NO is present under low-oxygen tension [38-40]. 
More research is necessary on these subjects (nitration, nitrosation, and metal nitrosylation) to understand why, and how, proteins are selectively modified by any of these post-translational modifications (PTMs).

Figure 1 depicts a simple model of the NO networking metabolism in plant cells where the main biochemical reactions including the mechanism of generation from L-arginine and nitrate/nitrite is outlined, as well as its interactions with other biomolecules. The generated NO, either from L-arginine by a NADPH-dependent NOS activity, or from nitrite/nitrite NADH-dependent NR activity, can react with different molecules, such as superoxide radicals $\left(\mathrm{O}_{2}{ }^{\bullet-}\right)$, to generate peroxynitrite $\left(\mathrm{ONOO}^{-}\right)$, which can mediate a process of protein tyrosine nitration and lead to nitro-oxidative stress. Alternatively, $\mathrm{NO}$ can react with reduced glutathione (GSH) in the presence of $\mathrm{O}_{2}$ to form $S$-nitrosoglutathione (GSNO). This metabolite can also interact with thiol-containing proteins by a process of $S$-nitrosation affecting their function, thus participating in cell signaling events. In this cascade of interactions, GSNO, through transcription factors, could also regulate a battery of genes involved in different metabolic pathways implicated in the mechanism of either cell signaling or in response to nitro-oxidative processes.

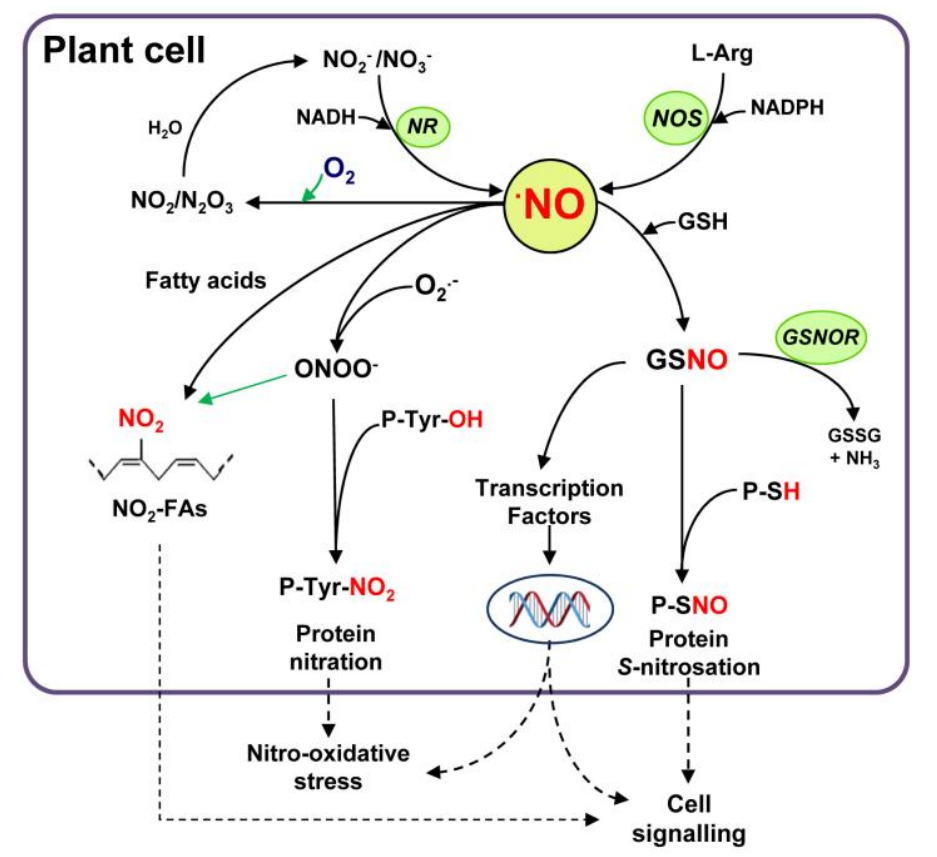

Figure 1. Outline of nitric oxide (NO) metabolism in plant cells. Nitric oxide can be generated, among others, by either nitrate reductase (NR) or by L-arginine-dependent nitric oxide synthase (NOS). Then, NO can react with reduced glutathione (GSH) to form S-nitrosoglutathione (GSNO) through a process of $S$-nitrosation (S-nitrosylation). This metabolite can be converted by the enzyme $S$-nitrosoglutathione reductase (GSNOR) into oxidized glutathione (GSSG) and $\mathrm{NH}_{3}$. GSNO and other $S$-nitrosothiols can interact with specific protein sulfhydryl groups (P-SH) to produce $S$-nitrosated proteins (P-SNO) in a process called S-transnitrosation, which can mediate signaling processes. Nitric oxide also interacts rapidly $\left(\mathrm{K} \sim 10^{10} \mathrm{M}^{-1} \mathrm{~s}^{-1}\right)$ with superoxide radicals $\left(\mathrm{O}_{2}{ }^{\bullet-}\right)$ to generate peroxynitrite $\left(\mathrm{ONOO}^{-}\right)$, a powerful oxidant molecule that can mediate the tyrosine nitration of proteins $\left(\mathrm{P}-\mathrm{Tyr}-\mathrm{NO}_{2}\right)$ and also the nitration of fatty acids $\left(\mathrm{NO}_{2}-\mathrm{FAs}\right)$. Alternatively, $\mathrm{NO}$ in the presence of oxygen is converted into dinitrogen trioxide $\left(\mathrm{N}_{2} \mathrm{O}_{3}\right)$ and nitrogen dioxide $\left(\mathrm{NO}_{2}\right)$ which, in aqueous solutions, are transformed into nitrite and nitrate. Nitric oxide and related molecules could be part of cell signaling or nitro-oxidative stress processes.

In addition to these NO-mediated PTMs, and as it has be mentioned previously, there are other bio-molecules in plants which can undergo functional modifications mediated by NO-derived 
molecules, such as fatty acids, which are converted into nitro-fatty acids $\left(\mathrm{NO}_{2}-\mathrm{FA}\right)$. Thus, recently, the presence of nitro-linolenic acid has been identified in the model plants Arabidopsis thaliana, the abundance of nitro-linolenic acid which changes during the development, the seeds being the organ with the higher concentration. Moreover, it was found that this molecule had signal functions under several abiotic stresses [17] with the capacity to release NO [41].

\section{NO Contributes to Plant Growth and Development}

The implication of NO in almost all physiological processes during the plant cycle has been demonstrated in many plant species. Some of those processes include seed and pollen germination [42-46], root development and plant growth [47-49], stomata movement [50,51], senescence [52,53], flower development [54], and fruit ripening [55-58].

As examples of this involvement of nitric oxide in plant physiology, the inverse correlation of NO content throughout fruit ripening and leaf senescence is established here. Figure 2a shows the phenotype of California sweet pepper (Capsicum annum L.) fruits at different ripening stages: green, breaking point, and red. This fruit is a non-climacteric one where it has been demonstrated that NO content diminishes during ripening, whereas other elements of the RNS metabolism change following patterns, such as an increase of protein nitration and SNOs content accompanied by a decreased S-nitrosoglutahione reductase activity [56-58]. In the case of pea (Pisum sativum) plants, behind the characteristic loss of chlorophyll during leaf senescence (Figure 2b), there is also a lower NO content accompanied by a strong enhancement in the generation of ROS and the decline of the antioxidative systems $[52,59]$.
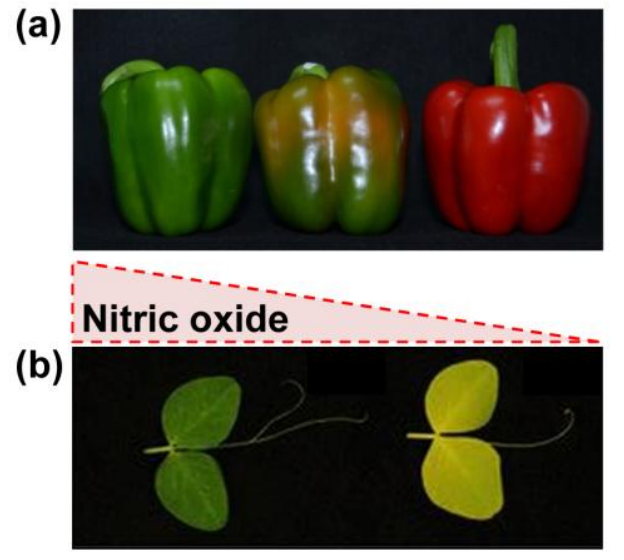

Figure 2. Nitric oxide (NO) content decreases during ripening of sweet pepper (Capsicum annum L.) fruits and senescence of pea (Pisum sativum L.) leaves. (a) Phenotype of pepper fruits at different ripening stages: green, breaking point and red); (b) Pea leaves from young and senescent pea plants (reproduced with permission from Photosynth. Res. (2013) 117: 221-234 [60] by Springer Nature and Copyright Clearance Center).

\section{NO is Involved in the Mechanism of Response against Both Abiotic and Biotic Stresses}

Plants are continuously exposed to a wide range of adverse environmental conditions, including drought, extreme temperature, atmospheric pollutants, salinity, heavy metals, nutrient deficiencies, and pathogens, among other factors, which usually limit agricultural production considerably. It is well known that many of these stresses may lead to an oxidative stress characterized by uncontrollable overproduction of ROS that generates molecular damage in proteins, lipids, and nucleic acids. However, it is also well documented that all these stresses trigger an imbalance of RNS production $[8,61,62]$. Nevertheless, in all these mechanisms of response it is important to elucidate if any of these reactive species act as signal molecules or could promote cellular damage. Moreover, the close metabolic interplay between these two families of molecules (ROS and RNS) should be 
considered in which many enzymes involved in ROS metabolism are modulated either by nitration, $S$-nitrosation, or both [63]. Another example of the connection between ROS and RNS has been described in the enzymatic system involved in the generation of $\mathrm{O}_{2}{ }^{\bullet-}$ during pathogen infection. In Arabidopsis, this enzyme is the respiratory burst oxidase homologue (Rboh) D, also known as NADPH oxidase, which can undergo a process of $S$-nitrosation at Cys890, which provokes its inhibition and, consequently, the lower production of $\mathrm{O}_{2}^{\bullet-}$ [64].

\section{Plant NO and Surrounding Atmosphere}

Thus far, the available information about the interchange (emission and uptake) of NO between plants with the surrounding atmosphere is relatively scarce [65]. One of the first observations on the capacity of plants to release NO to the atmosphere was detected in soybean plants treated with herbicides [66]. Years later, this phenomenon was also observed under physiological conditions [67]. However, the physiological reasons of this emission are not clear and some authors consider that it could be a mechanism to eliminate the excess of nitrite, thus avoiding its toxicity. In relation to the atmospheric NO uptake by plants, there are several potential concerns considering that the absorption of NO could mimic the function of the endogenous NO or substitute a potential NO deficiency $[68,69]$. In any case, one of the beneficial effects of this NO uptake by plants is that it can reduce the overall concentration of NOx in the atmosphere and potentially improve the air quality [70].

\section{Potential Agricultural Applications of NO}

The number of reports showing the beneficial effects of exogenous application of NO by different procedures is increasing with time. Thus, it has been demonstrated that the provision of exogenous NO can mitigate the adverse effects of different environmental stresses such as heavy metal stress, salinity, or UV radiation, regulates seed germination, delays fruit ripening, and increases shelf-life and improved life quality of detached flowers [71]. It is remarkable that, in many cases, the beneficial effects of $\mathrm{NO}$ are through the stimulation of the antioxidant systems $[57,72,73]$ which, again, highlights the close interrelationship between RNS and ROS metabolisms.

\section{Conclusions and Future Perspectives}

In plants, NO and its RNS-derived family have become a new area of research since they have multiple interactions under physiological and adverse stress conditions. Moreover, our knowledge about the potential beneficial effects of the exogenous application of NO throughout different approaches, either by gas or using NO donors, which allows palliating adverse effects of plant of agronomical interest in different areas (alleviating heavy metals contaminations, improving seed germination, or extending postharvest management of fruits and vegetables) opens new avenues of research. Although significant advances have been obtained about the NO roles in higher plants, there are still challenges to understand how NO and derived molecules can function at the molecular level and how the intimate mechanisms of interaction with other signaling molecules work out.

Author Contributions: F.J.C. wrote the paper and J.M.P. discussed it.

Acknowledgments: Research in our laboratory is supported by the ERDF-co-financed grant AGL2015-65104-P from the Ministry of Economy and Competitiveness, Spain.

Conflicts of Interest: The authors declare no conflict of interest.

\section{References}

1. Capron, T.M.; Mansfield, T.A. Generation of nitrogen oxide pollutants during $\mathrm{CO}_{2}$ enrichment of glasshouse atmospheres. J. Hortic. Sci. 1975, 50, 233-238. [CrossRef]

2. Anderson, L.S.; Mansfield, T.A. The effects of nitric oxide pollution on the growth of tomato. Environ. Pollut. 1979, 20, 113-121. [CrossRef] 
3. Palmer, R.M.; Ferrige, A.G.; Moncada, S. Nitric oxide release accounts for the biological activity of endothelium-derived relaxing factor. Nature 1987, 327, 524-526. [CrossRef] [PubMed]

4. Ignarro, L.J.; Buga, G.M.; Wood, K.S.; Byrns, R.E.; Chaudhuri, G. Endothelium-derived relaxing factor produced and released from artery and vein is nitric oxide. Proc. Natl. Acad. Sci. USA 1987, 84, 9265-9269. [CrossRef] [PubMed]

5. Alderton, W.K.; Cooper, C.E.; Knowles, R.G. Nitric oxide synthases: Structure, function and inhibition. Biochem. J. 2001, 357, 593-615. [CrossRef] [PubMed]

6. Fewson, C.A.; Nicholas, D.J.D. Utilization of nitric oxide by microorganisms and higher plants. Nature 1960, 188, 794-796. [CrossRef] [PubMed]

7. Klepper, L.A. Nitric oxide and nitrogen dioxide $\left(\mathrm{NO}_{2}\right)$ emissions from herbicide-treated soybean plants. Atmos. Environ. 1979, 13, 537-542. [CrossRef]

8. Corpas, F.J.; Leterrier, M.; Valderrama, R.; Airaki, M.; Chaki, M.; Palma, J.M.; Barroso, J.B. Nitric oxide imbalance provokes a nitrosative response in plants under abiotic stress. Plant Sci. 2011, 181, 604-611. [CrossRef] [PubMed]

9. Yoshioka, H.; Mase, K.; Yoshioka, M.; Kobayashi, M.; Asai, S. Regulatory mechanisms of nitric oxide and reactive oxygen species generation and their role in plant immunity. Nitric Oxide 2011, 25, 216-221. [CrossRef] [PubMed]

10. Puppo, A.; Pauly, N.; Boscari, A.; Mandon, K.; Brouquisse, R. Hydrogen peroxide and nitric oxide: Key regulators of the Legume-Rhizobium and mycorrhizal symbioses. Antioxid. Redox Signal. 2013, 18, 2202-2219. [CrossRef] [PubMed]

11. Hong, J.K.; Yun, B.W.; Kang, J.G.; Raja, M.U.; Kwon, E.; Sorhagen, K.; Chu, C.; Wang, Y.; Loake, G.J. Nitric oxide function and signalling in plant disease resistance. J. Exp. Bot. 2008, 59, 147-154. [CrossRef] [PubMed]

12. Broniowska, K.A.; Diers, A.R.; Hogg, N. S-nitrosoglutathione. Biochim. Biophys. Acta 2013, 1830, $3173-3181$. [CrossRef] [PubMed]

13. Begara-Morales, J.C.; Sánchez-Calvo, B.; Luque, F.; Leyva-Pérez, M.O.; Leterrier, M.; Corpas, F.J.; Barroso, J.B. Differential transcriptomic analysis by RNA-Seq of GSNO-responsive genes between Arabidopsis roots and leaves. Plant Cell Physiol. 2014, 55, 1080-1095. [CrossRef] [PubMed]

14. Mata-Pérez, C.; Begara-Morales, J.C.; Chaki, M.; Sánchez-Calvo, B.; Valderrama, R.; Padilla, M.N.; Corpas, F.J.; Barroso, J.B. Protein tyrosine nitration during development and abiotic stress response in plants. Front. Plant Sci. 2016, 7, 1699. [CrossRef] [PubMed]

15. Imran, Q.M.; Hussain, A.; Lee, S.U.; Mun, B.G.; Falak, N.; Loake, G.J.; Yun, B.W. Transcriptome profile of NO-induced Arabidopsis transcription factor genes suggests their putative regulatory role in multiple biological processes. Sci. Rep. 2018, 8, 771. [CrossRef] [PubMed]

16. Huang, J.; Wei, H.; Li, L.; Yu, S. Transcriptome analysis of nitric oxide-responsive genes in upland cotton (Gossypium hirsutum). PLoS ONE 2018, 13, e0192367. [CrossRef] [PubMed]

17. Mata-Pérez, C.; Sánchez-Calvo, B.; Padilla, M.N.; Begara-Morales, J.C.; Luque, F.; Melguizo, M.; Jiménez-Ruiz, J.; Fierro-Risco, J.; Peñas-Sanjuán, A.; Valderrama, R.; et al. Nitro-fatty acids in plant signaling: Nitro-linolenic acid induces the molecular chaperone network in Arabidopsis. Plant Physiol. 2016, 170, 686-701. [CrossRef] [PubMed]

18. Corpas, F.J.; Chaki, M.; Leterrier, M.; Barroso, J.B. Protein tyrosine nitration: A new challenge in plants. Plant Signal Behav. 2009, 4, 920-923. [CrossRef] [PubMed]

19. Kolbert, Z.; Feigl, G.; Bordé, Á.; Molnár, Á.; Erdei, L. Protein tyrosine nitration in plants: Present knowledge, computational prediction and future perspectives. Plant Physiol. Biochem. 2017, 113, 56-63. [CrossRef] [PubMed]

20. Chaki, M.; Valderrama, R.; Fernández-Ocaña, A.M.; Carreras, A.; López-Jaramillo, J.; Luque, F.; Palma, J.M.; Pedrajas, J.R.; Begara-Morales, J.C.; Sánchez-Calvo, B.; et al. Protein targets of tyrosine nitration in sunflower (Helianthus annuus L.) hypocotyls. J. Exp. Bot. 2009, 60, 4221-4234. [CrossRef] [PubMed]

21. Cecconi, D.; Orzetti, S.; Vandelle, E.; Rinalducci, S.; Zolla, L.; Delledonne, M. Protein nitration during defense response in Arabidopsis thaliana. Electrophoresis 2009, 30, 2460-2468. [CrossRef] [PubMed]

22. Lozano-Juste, J.; Colom-Moreno, R.; León, J. In Vivo protein tyrosine nitration in Arabidopsis thaliana. J. Exp. Bot. 2011, 62, 3501-3517. [CrossRef] [PubMed] 
23. Begara-Morales, J.C.; Chaki, M.; Sánchez-Calvo, B.; Mata-Pérez, C.; Leterrier, M.; Palma, J.M.; Barroso, J.B.; Corpas, F.J. Protein tyrosine nitration in pea roots during development and senescence. J. Exp. Bot. 2013, 64, 1121-1134. [CrossRef] [PubMed]

24. Szuba, A.; Kasprowicz-Maluśki, A.; Wojtaszek, P. Nitration of plant apoplastic proteins from cell suspension cultures. J. Proteom. 2015, 120, 158-168. [CrossRef] [PubMed]

25. Begara-Morales, J.C.; Sánchez-Calvo, B.; Chaki, M.; Valderrama, R.; Mata-Pérez, C.; López-Jaramillo, J.; Padilla, M.N.; Carreras, A.; Corpas, F.J.; Barroso, J.B. Dual regulation of cytosolic ascorbate peroxidase (APX) by tyrosine nitration and S-nitrosylation. J. Exp. Bot. 2014, 65, 527-538. [CrossRef] [PubMed]

26. Begara-Morales, J.C.; Sánchez-Calvo, B.; Chaki, M.; Mata-Pérez, C.; Valderrama, R.; Padilla, M.N.; López-Jaramillo, J.; Luque, F.; Corpas, F.J.; Barroso, J.B. Differential molecular response of monodehydroascorbate reductase and glutathione reductase by nitration and S-nitrosylation. J. Exp. Bot. 2015, 66, 5983-5996. [CrossRef] [PubMed]

27. Begara-Morales, J.C.; Chaki, M.; Valderrama, R.; Sánchez-Calvo, B.; Mata-Pérez, C.; Padilla, M.N.; Corpas, F.J.; Barroso, J.B. NO buffering and conditional NO release in stress response. J. Exp. Bot. 2018. [CrossRef] [PubMed]

28. Lindermayr, C.; Saalbach, G.; Durner, J. Proteomic identification of S-nitrosylated proteins in Arabidopsis. Plant Physiol. 2005, 137, 921-930. [CrossRef] [PubMed]

29. Fares, A.; Rossignol, M.; Peltier, J.B. Proteomics investigation of endogenous S-nitrosylation in Arabidopsis. Biochem. Biophys. Res. Commun. 2011, 416, 331-336. [CrossRef] [PubMed]

30. Begara-Morales, J.C.; López-Jaramillo, F.J.; Sánchez-Calvo, B.; Carreras, A.; Ortega-Muñoz, M.; Santoyo-González, F.; Corpas, F.J.; Barroso, J.B. Vinyl sulfone silica: Application of an open preactivated support to the study of transnitrosylation of plant proteins by S-nitrosoglutathione. BMC Plant Biol. 2013, 13, 61. [CrossRef] [PubMed]

31. Puyaubert, J.; Fares, A.; Rézé, N.; Peltier, J.B.; Baudouin, E. Identification of endogenously S-nitrosylated proteins in Arabidopsis plantlets: Effect of cold stress on cysteine nitrosylation level. Plant Sci. 2014, 215-216, 150-156. [CrossRef] [PubMed]

32. Sehrawat, A.; Deswal, R. S-nitrosylation analysis in Brassica juncea apoplast highlights the importance of nitric oxide in cold-stress signaling. J. Proteome Res. 2014, 13, 2599-2619. [CrossRef] [PubMed]

33. Sehrawat, A.; Deswal, R. Sub-proteome S-nitrosylation analysis in Brassica juncea hints at the regulation of Brassicaceae specific as well as other vital metabolic pathway(s) by nitric oxide and suggests post-translational modifications cross-talk. Nitric Oxide 2014, 43, 97-111. [CrossRef] [PubMed]

34. Gietler, M.; Nykiel, M.; Orzechowski, S.; Fettke, J.; Zagdańska, B. Proteomic analysis of S-nitrosylated and S-glutathionylated proteins in wheat seedlings with different dehydration tolerances. Plant Physiol. Biochem. 2016, 108, 507-518. [CrossRef] [PubMed]

35. Zaffagnini, M.; De Mia, M.; Morisse, S.; Di Giacinto, N.; Marchand, C.H.; Maes, A.; Lemaire, S.D.; Trost, P. Protein S-nitrosylation in photosynthetic organisms: A comprehensive overview with future perspectives. Biochim. Biophys. Acta 2016, 1864, 952-966. [CrossRef] [PubMed]

36. Henry, Y.; Guissani, A. Interactions of nitric oxide with hemoproteins: Roles of nitric oxide in mitochondria. Cell. Mol. Life Sci. 1999, 55, 1003-1014. [CrossRef] [PubMed]

37. Zhang, S.; Melzer, M.M.; Sen, S.N.; Çelebi-Ölçüm, N.; Warren, T.H. A motif for reversible nitric oxide interactions in metalloenzymes. Nat. Chem. 2016, 8, 663-669. [CrossRef] [PubMed]

38. Dordas, C.; Rivoal, J.; Hill, R.D. Plant haemoglobins, nitric oxide and hypoxic stress. Ann. Bot. 2003, 91, 173-178. [CrossRef] [PubMed]

39. Gupta, K.J.; Hebelstrup, K.H.; Mur, L.A.; Igamberdiev, A.U. Plant hemoglobins: Important players at the crossroads between oxygen and nitric oxide. FEBS Lett. 2011, 585, 3843-3849. [CrossRef] [PubMed]

40. Hebelstrup, K.H.; van Zanten, M.; Mandon, J.; Voesenek, L.A.; Harren, F.J.; Cristescu, S.M.; Møller, I.M.; Mur, L.A. Haemoglobin modulates NO emission and hyponasty under hypoxia-related stress in Arabidopsis thaliana. J. Exp. Bot. 2012, 63, 5581-5591. [CrossRef] [PubMed]

41. Mata-Pérez, C.; Sánchez-Calvo, B.; Begara-Morales, J.C.; Carreras, A.; Padilla, M.N.; Melguizo, M.; Valderrama, R.; Corpas, F.J.; Barroso, J.B. Nitro-linolenic acid is a nitric oxide donor. Nitric Oxide 2016, 5, 57-63. [CrossRef] [PubMed]

42. Bethke, P.C.; Libourel, I.G.; Jones, R.L. Nitric oxide reduces seed dormancy in Arabidopsis. J. Exp. Bot. 2006, 57, 517-526. [CrossRef] [PubMed] 
43. Prado, A.M.; Colaço, R.; Moreno, N.; Silva, A.C.; Feijó, J.A. Targeting of pollen tubes to ovules is dependent on nitric oxide (NO) signaling. Mol. Plant 2008, 1, 703-714. [CrossRef] [PubMed]

44. Šírová, J.; Sedlářová, M.; Piterková, J.; Luhová, L.; Petřivalský, M. The role of nitric oxide in the germination of plant seeds and pollen. Plant Sci. 2011, 181, 560-572. [CrossRef] [PubMed]

45. Albertos, P.; Romero-Puertas, M.C.; Tatematsu, K.; Mateos, I.; Sánchez-Vicente, I.; Nambara, E.; Lorenzo, O. $S$-nitrosylation triggers ABI5 degradation to promote seed germination and seedling growth. Nat. Commun. 2015, 6, 8669. [CrossRef] [PubMed]

46. Sanz, L.; Albertos, P.; Mateos, I.; Sánchez-Vicente, I.; Lechón, T.; Fernández-Marcos, M.; Lorenzo, O. Nitric oxide (NO) and phytohormones crosstalk during early plant development. J. Exp. Bot. 2015, 66, 2857-2868. [CrossRef] [PubMed]

47. Pagnussat, G.C.; Lanteri, M.L.; Lombardo, M.C.; Lamattina, L. Nitric oxide mediates the indole acetic acid induction activation of a mitogen-activated protein kinase cascade involved in adventitious root development. Plant Physiol. 2004, 135, 279-286. [CrossRef] [PubMed]

48. Corpas, F.J.; Barroso, J.B.; Carreras, A.; Valderrama, R.; Palma, J.M.; León, A.M.; Sandalio, L.M.; del Río, L.A. Constitutive arginine-dependent nitric oxide synthase activity in different organs of pea seedlings during plant development. Planta 2006, 224, 246-254. [CrossRef] [PubMed]

49. Corpas, F.J.; Barroso, J.B. Functions of nitric oxide (NO) in roots during development and under adverse stress conditions. Plants (Basel) 2015, 4, 240-252. [CrossRef] [PubMed]

50. Neill, S.; Barros, R.; Bright, J.; Desikan, R.; Hancock, J.; Harrison, J.; Morris, P.; Ribeiro, D.; Wilson, I. Nitric oxide, stomatal closure, and abiotic stress. J. Exp. Bot. 2008, 59, 165-176. [CrossRef] [PubMed]

51. Shi, K.; Li, X.; Zhang, H.; Zhang, G.; Liu, Y.; Zhou, Y.; Xia, X.; Chen, Z.; Yu, J. Guard cell hydrogen peroxide and nitric oxide mediate elevated $\mathrm{CO}_{2}$-induced stomatal movement in tomato. New Phytol. 2015, 208, 342-353. [CrossRef] [PubMed]

52. Corpas, F.J.; Barroso, J.B.; Carreras, A.; Quirós, M.; León, A.M.; Romero-Puertas, M.C.; Esteban, F.J.; Valderrama, R.; Palma, J.M.; Sandalio, L.M.; et al. Cellular and subcellular localization of endogenous nitric oxide in young and senescent pea plants. Plant Physiol. 2004, 136, 2722-2733. [CrossRef] [PubMed]

53. Procházková, D.; Wilhelmová, N. Nitric oxide, reactive nitrogen species and associated enzymes during plant senescence. Nitric Oxide 2011, 24, 61-65. [CrossRef] [PubMed]

54. Zafra, A.; Rodríguez-García, M.I.; Alché, J.D. Cellular localization of ROS and NO in olive reproductive tissues during flower development. BMC Plant Biol. 2010, 10, 36-53. [CrossRef] [PubMed]

55. Leshem, Y.Y.; Pinchasov, Y. Non-invasive photoacoustic spectroscopic determination of relative endogenous nitric oxide and ethylene content stoichiometry during the ripening of strawberries Fragaria anannasa (Duch.) and avocados Persea americana (Mill.). J. Exp. Bot. 2000, 51, 1471-1473. [PubMed]

56. Chaki, M.; Álvarez de Morales, P.; Ruiz, C.; Begara-Morales, J.C.; Barroso, J.B.; Corpas, F.J.; Palma, J.M. Ripening of pepper (Capsicum annuum) fruit is characterized by an enhancement of protein tyrosine nitration. Ann. Bot. 2015, 116, 637-647. [CrossRef] [PubMed]

57. Rodríguez-Ruiz, M.; Mateos, R.M.; Codesido, V.; Corpas, F.J.; Palma, J.M. Characterization of the galactono-1,4-lactone dehydrogenase from pepper fruits and its modulation in the ascorbate biosynthesis. Role of nitric oxide. Redox Biol. 2017, 12, 171-181. [CrossRef] [PubMed]

58. Rodríguez-Ruiz, M.; Mioto, P.; Palma, J.M.; Corpas, F.J. S-nitrosoglutathione reductase (GSNOR) activity is down-regulated during pepper (Capsicum annuum L.) fruit ripening. Nitric Oxide 2017, 68, 51-55. [CrossRef] [PubMed]

59. Del Río, L.A.; Pastori, G.M.; Palma, J.M.; Sandalio, L.M.; Sevilla, F.; Corpas, F.J.; Jiménez, A.; López-Huertas, E.; Hernández, J.A. The activated oxygen role of peroxisomes in senescence. Plant Physiol. 1998, 116, 1195-1200. [CrossRef] [PubMed]

60. Kusaba, M.; Tanaka, A.; Tanaka, R. Stay-green plants: What do they tell us about the molecular mechanism of leaf senescence. Photosynth. Res. 2013, 117, 221-234. [CrossRef] [PubMed]

61. Arasimowicz-Jelonek, M.; Floryszak-Wieczorek, J.; Gwózdz, E.A. The message of nitric oxide in cadmium challenged plants. Plant Sci. 2011, 181, 612-620. [CrossRef] [PubMed]

62. Trapet, P.; Kulik, A.; Lamotte, O.; Jeandroz, S.; Bourque, S.; Nicolas-Francès, V.; Rosnoblet, C.; Besson-Bard, A.; Wendehenne, D. NO signaling in plant immunity: A tale of messengers. Phytochemistry 2015, 112, 72-79. [CrossRef] [PubMed] 
63. Begara-Morales, J.C.; Sánchez-Calvo, B.; Chaki, M.; Valderrama, R.; Mata-Pérez, C.; Padilla, M.N.; Corpas, F.J.; Barroso, J.B. Antioxidant systems are regulated by nitric oxide-mediated post-translational modifications (NO-PTMs). Front. Plant Sci. 2016, 7, 152. [CrossRef] [PubMed]

64. Yun, B.W.; Feechan, A.; Yin, M.; Saidi, N.B.; Le Bihan, T.; Yu, M.; Moore, J.W.; Kang, J.G.; Kwon, E.; Spoel, S.H.; et al. S-nitrosylation of NADPH oxidase regulates cell death in plant immunity. Nature 2011, 478, $264-268$. [CrossRef] [PubMed]

65. Corpas, F.J.; Palma, J.M.; del Río, L.A.; Barroso, J.B. Nitric oxide emission and uptake from higher plants. In Gasotransmitters in Plants, Signaling and Communication in Plants; Lamattina, L.C., García-Mata, C., Eds.; Springer International Publishing: Cham, Switzerland, 2016; pp. 79-93.

66. Chen, J.; Wu, F.H.; Liu, T.W.; Chen, L.; Xiao, Q.; Dong, X.J.; He, J.X.; Pei, Z.M.; Zheng, H.L. Emissions of nitric oxide from 79 plant species in response to simulated nitrogen deposition. Environ. Pollut. 2012, 160, 192-200. [CrossRef] [PubMed]

67. Saxe, $\mathrm{H}$. Effects of $\mathrm{NO}, \mathrm{NO}_{2}$ and $\mathrm{CO}_{2}$ on net photosynthesis, dark respiration and transpiration of pot plants. New Phytol. 1986, 103, 185-197. [CrossRef]

68. Saxe, H. Stomatal-dependent and stomatal-independent uptake of NOx. New Phytol. 1986, 103, $199-205$. [CrossRef]

69. Eller, A.D.; Sparks, J.P. Predicting leaf-level fluxes of $\mathrm{O}_{3}$ and $\mathrm{NO}_{2}$ : The relative roles of diffusion and biochemical processes. Plant Cell Environ. 2006, 29, 1742-1750. [CrossRef] [PubMed]

70. Marvasi, M. Potential use and perspectives of nitric oxide donors in agriculture. J. Sci. Food Agric. 2017, 97, 1065-1072. [CrossRef] [PubMed]

71. Ahmad, P.; Abdel Latef, A.A.; Hashem, A.; Abd Allah, E.F.; Gucel, S.; Tran, L.S. Nitric oxide mitigates salt stress by regulating levels of osmolytes and antioxidant enzymes in chickpea. Front. Plant Sci. 2016, 7, 347. [CrossRef] [PubMed]

72. Manai, J.T.; Kalai, T.; Gouia, H.; Corpas, F.J. Exogenous nitric oxide (NO) ameliorates salinity-induced oxidative stress in tomato (Solanum lycopersicum) plants. J. Soil Sci. Plant Nutr. 2014, 14, 433-446. [CrossRef]

73. Kharbech, O.; Houmani, H.; Chaoui, A.; Corpas, F.J. Alleviation of Cr(VI)-induced oxidative stress in maize (Zea mays L.) seedlings by $\mathrm{NO}$ and $\mathrm{H}_{2} \mathrm{~S}$ donors through differential organ-dependent regulation of ROS and NADPH-recycling metabolisms. J. Plant Physiol. 2017, 219, 71-80. [CrossRef] [PubMed] 